\title{
GAS CHROMATOGRAPHY COMBINED TO MASS SPECTROMETRY ANALYSES OF SOME CITRUS PEELS BIOACTIVE COMPOUNDS AGAINST THE COTTON LEAFWORM, SPODOPTERA LITTORALIS (BOISD.)
}

\author{
LOBNA R. AMIN ${ }^{1}$, S. A. ABO-EL-ENEIN ${ }^{2}$, A. M. ABDEL-GHANY ${ }^{1}$, S.S.EL- \\ BADAWY ${ }^{1}$ AND T.R.AMIN ${ }^{1}$
}

1- Plant protection Research Institute, ARC, Dokki, Giza, Egypt.

2- Chemistry Dept., Faculty of science, Ain-Shams University, Egypt.

(Manuscript received 1 November 2017)

\begin{abstract}
$\mathrm{H}$ exane (Hex) extracts of fresh navel orange (citrus sinensis) and lemon (citrus limon) peel were prepared to isolate and identify toxic bioactive secondary metabolites for potential use as natural ecofriendly biopesticides against the cotton leafworm, Spodoptera littoralis (Boisd.) (Lepidoptera: Noctuidae). Hex extracts were fractionated by column chromatography. The fractions that showed activity against the larvae, were identified and quantified by gas chromatography combined to mass spectrometry(GC/MS), after checking component profile by thin layer chromatography (TLC). The results revealed that $F_{2}$ and $F_{3}$ fractions were the toxic active fractions of both lemon and orange peel Hex extracts, but lemon fractions were more toxic than orange ones. $F_{2}$ and $F_{3}$ fractions of orange extract causd 60 and $20 \%$ larval mortality, respectively. Both lemon extract fractions caused $100 \%$ morality. Orange fractions had approximately equal dlimonene content $(\approx 86 \%)$ as illustrated by mass spectral fragmentation pattern. However, $F_{2}$ fraction contained slightly higher amounts of linalool, a-terpinol and citral than $\mathrm{F}_{3}$ fraction. The active fraction of both lemon and orange peel extracts contained d-limonene, a-pinene, linalool, citronllal and citral. Limonene oxide, geranial and terpineol were only detected in orange peel extracts. The results indicated that secondary metabolites quality and quantity differ according to the citrus spp., and the quantity of d-limonene is much lower $(\approx 15 \%)$ in lemon than orange extracts in spite of lemon peel was more toxic than the orange. However, d-limonene was a major compound in both extracts. The results suggest that citrus extract contains many toxic compounds, other than limonene, and /or they could potentiate each other to give the observed toxicity. It could be concluded that the quantity of d-limonene is not a determinant factor, but it is probable that other metabolites confer toxicity allover citrus extract depending on the species.

Keywords: natural biopesticides, citrus, cotton leafworm, toxicity,
\end{abstract} fractions, GC/MS analysis.

\section{INTRODUCTION}

Numerous investigations have been performed at identifying chemical composition of extracts from different Citrus species. Citrus fruits are sources of 
16 GAS CHROMATOGRAPHY COMBINED TO MASS SPECTROMETRY ANALYSES OF SOME CITRUS PEELS BIOACTIVE COMPOUNDS AGAINST THE COTTON LEAFWORM, SPODOPTERA LITTORALIS (BOISD.)

essential oils (EOs) due to their aromatic secondary metabolites which usually obtained from the peels. Peels of citrus fruits comprise of two layers, orange outer layer as flavedo and inner white layer as albedo. The flavedo layer contains EOs in the range of 0.5 to $3 \mathrm{Kg} /$ ton of fruit (Sattar and Mahmud,1992). Eos are vegetable products whose constituents are basically complex mixture of terpenic hydrocarbons and oxygenated derivatives such as aldhydes, alcohols and esters (Murugan et al.,2012). Unlike most major plant species, citrus plants contain a large volume of Eos and mostly composed of monoterpene compounds (Weiss, 1997). However, the composition and flavor quality of citrus fruits considerably depend on their cultivar, maturity, genotype, origin, climate, season and ripening stage (Parastar et al. , 2012).

Citrus species have been reported as a source of botanical insecticides. Peel and seed solvent extracts from a variety of citrus plants contain secondary metabolites that show insecticidal activity against several insect species (Salvatore et al. ,2004 ; Siskos et al. , 2007 ; Loh et al. , 2011). Identification of toxic secondary metabolites constituents could be the first step in the investigation of natural insecticides based on peel waste. Among different methods, gas chromatography combined to mass spectrometry (GC-MS) is the primary choice for the analysis of citrus extracts by many investigators (e.g Parastar et al. , 2012).

Oxygenated monoterpene aldhydes like citral, are reported to be responsible for the chemical resistance of lemon to attack by Ceratitis Capitata (da Silva Branco et al. 2000). It is northworthy that limonene was the major component in all EOs analysed (Dutra et al., 2016). However, there are toxic bioactive compounds like pinene (Michaelakis et al., 2009) and linalool (Yamaski et al., 2007).

Among various species of agricultural pests, the cotton leafworm Spodoptera littoralis (Boisd.) is one of major polyphagous pest which attacks economically important crops in Egypt such as cotton, cabbage and vegetables causing extensive dmage. Studies concerned with bioactivity of citrus peels against this pest are relatively few. Amin et al. (2017) studied bioactivity of fresh navel orange and lemon peels crude extracts against $S$.littoralis larvae. They found that the bioactivity depends on solvent of extraction, Citrus species and method of treatment. Hexane (Hex)extract was more efficient than methanol extract specially for contact treatment. So Hex extracts were selected for further studies in this topic.

The aim of this paper was to extract, isolate and identify toxic bioactive secondary metabolites of fresh navel orange (Citrus sinensis) and lemon (citrus limon) peel Hex extracts for potential use against the cotton leafworm, S. littoralis. Chemical composition of lemon and orange extracts were compared to detect the differences and significance between the two species with respect to their toxic constituents. Thin layer chromatography (TLC) and advanced gas chromatography techniques were used. 


\section{MATERIALS AND METHODS}

\section{- Collection of citrus fruits :}

Navel orange and lemon fruits were fresh and of eating quality, and purchased from local market during citrus season (october-january). They were brought to the laboratory, and the fruits were cleaned thoroughly by washing with tap water in order to clean dust or any particles. Fruits were inspected carefully to find any kind of diseases or pest infestation, and the infested ones were discarded. Fruits were kept in a refrigerator $\left(2-8^{\circ} \mathrm{C}\right)$ for few days till be used for extraction.

\section{- Chemicals :}

Silica gel used for fractionation on column chromatography was Kiesel gel 60 (70-230 and 230-400 mesh, Merck). TLC strips $20 \times 20 \mathrm{~cm}$ was purchased from Merck. Ethyl acetate (EtOAc), Hex and methanol $(\mathrm{MeOH})$ were provided by the company sigma Aldrich, while dichloromethane $\left(\mathrm{CH}_{2} \mathrm{Cl}_{2}\right)$ was from Analar. All solvents were HPLC grade.

\section{- Extraction :}

About $10 \mathrm{~kg}$ of navel orange or $5 \mathrm{~kg}$ of lemon fruits were dissected to get peels. The peels were weighed and cut into small pieces. Each $1 \mathrm{~kg}$ of peels were homogenized with 1 liter of absolute Hex for $5 \mathrm{~min}$ in electric blinder. The resultant homogenate was macerated for $72 \mathrm{hr}$, at room temperature, in a double amount of the used solvent to ensure efficient extraction. The homogenate was filtered using filter paper (Whatman No. 1). The filterates were concentrated to dryness under vaccum pressure using rotary evaporator (Labconco, Germany) at $35^{\circ} \mathrm{C}$. The resultant plant residue was considered as crude extract. It collected in a glass stoppered tubes and strored at $-10^{\circ} \mathrm{C}$ in a deep freezer till use.

\section{- Fractionation procedure of the Hex peel extracts:}

Hex extracts of orange and lemon peels were subjected to fractionation by column chromatography to isolate active metabolites in the extracts. Half gm of extract was mixed with $1 \mathrm{gm}$ of silica gel then transefered onto the column (75 x 11 mm, silica gel 70-230 mesh, Merck Kieselgel 60), as described by Kirchner, (1978). Extract was eluted initially with $n$-hexane then introducing $n$-hexane: ethyl acetate $(90: 10,80: 20,70: 30,60: 40,50: 50,40: 60,30: 70.20: 80,10: 90$, each of $10 \mathrm{ml} \mathrm{v} / \mathrm{v}$, respectively). Then $\mathrm{MeOH}$ was employed to remove components not removed by the other mobile phases. As soon as column chromatography was completed, the obtained fractions were concentrated under a stream of nitrogen for complexity analysis using thin layer chromatographic plates (TLC) and visualized by spraying with vanillin reagent according to the method mentioned by Kirchner (1978). 
18 GAS CHROMATOGRAPHY COMBINED TO MASS SPECTROMETRY ANALYSES OF SOME CITRUS PEELS BIOACTIVE COMPOUNDS AGAINST THE COTTON LEAFWORM, SPODOPTERA LITTORALIS (BOISD.)

Fractions which showed bioactivity against the experimental insect were rechromatographed using similar silica column but eluted with $n$-hexane- $\mathrm{CH}_{2} \mathrm{Cl}_{2}$ as a solvent system. For each fraction, the column was eluted successively with $100 \% n$ hexane, and $n$-hexane- $\mathrm{CH}_{2} \mathrm{Cl}_{2}$ mixtures, initially at $1 \% \mathrm{CH}_{2} \mathrm{Cl}_{2}$ in $n$-hexane and increasing $\mathrm{CH}_{2} \mathrm{Cl}_{2}$ by $1 \%$ to $10 \%$ then by $10 \%$ to $100 \% \mathrm{CH}_{2} \mathrm{Cl}_{2}$. Then $\mathrm{MeOH}$ was employed to remove components not removed by the other mobile phases. Then all fractions were identified by GC/MS system.

\section{- TLC analysis:}

TLC analysis was carried out according to Kirchner (1978) in order to check the component profile obtained from fractionation. TLC was performed on $20 \times 20 \mathrm{~cm}$ TLC plates silica gel $60 \mathrm{~F}_{254}$ precoated. Lemon and navel orange Hex fractions $(100 \mu \mathrm{g} / 5 \mathrm{ml}$ Hex) were spotted on the middle of the starting line $(1 \mathrm{~cm}$ away from one end of the plate). The plate was put into covered beaker and its inner surface was lined with filter paper to aid in saturating the atmosphere with solvent vapor. Fifty milliiters of solvent mixture $(60 \%$ Hex and $40 \%$ EtOAc.) were poured into the beaker, whereas the level of the fraction spots on TLC plate was above the solvent level. After development the plates were air dried for $10 \mathrm{~min}$ at room temperature. Photographs of the TLC plates were obtained by a sony digital camera ( $4 \mathrm{x}$ optical zoom) under UV light $(254 \mathrm{~nm}$ ) provided by a spectroline lamp or after staining by vanillin reagent . Similar fractions were collected together and kept in a deep freezer tell use for bioassay and GGc/Ms analysis.

\section{- GC/MS analysis :}

Secondary metabolites of the reported fractions that showed activity against larvae, were identified and quantified by chromatographic analyses. GC/MS analyses were performed on Gas Chromatograph-Mass spectrometry Agilent technologies GC 7890B system,5977A MSD detector (USA). Gas Chromatography/mass spectrometer system under computer control at $70 \mathrm{eV}$. The mobile phase is Helium high purity (99.9999\% pure) used at a flow rate of $1 \mathrm{ml} / \mathrm{min}$. The instrument equipped with a capillary column HB-5MS (30 m length, $0.25 \mathrm{~mm}$ thickness, $0.25 \mathrm{~m}$ diameter). $1 \mu \mathrm{l}$ sample was injected into the split/splitless inlet in split mode ratio 50 at $250{ }^{\circ} \mathrm{C}$ using a micro syringe. The temperature of the GC/MS interface was $250^{\circ} \mathrm{C}$ and temperature of ion source $200^{\circ} \mathrm{C}$. The oven temperature program started at $50^{\circ} \mathrm{C}$ hold $0.5 \mathrm{~min}$ increase of $10^{\circ} \mathrm{C} / \mathrm{min}$ to $190^{\circ} \mathrm{C}$, hold $1 \mathrm{~min}$ and increasing by $10^{\circ} \mathrm{C} / \mathrm{min}$ to reach $220^{\circ} \mathrm{Cm}$ hold $1 \mathrm{~min}$ and increasing by $10^{\circ} \mathrm{C} / \mathrm{min}$ to reach $300^{\circ} \mathrm{Cm}$ hold $2 \mathrm{~min}$. the range of scan mode (50-550 amu) used for data acquisition. The M/Z (Mass / Charge) ratio obtained was calibrated from the graph obtained, which was called as the Mass spectrum graph which is the fingerprint of a molecule. 
Identification of constituents present was based on comparing with computer matching of their retention indices and mass spectra fragmentation patterns against the library spectra Wiley330.000 and NIST08.LIB, (Adams, 2007). built up using pure substances and components of known constituents. The percentage of composition was computed from gas chromatography peak areas.

The chemical composition of peel extracts was assessed at analytical laboratories of central agricultural pesticides laboratory (CAPL), by the aid of Dr. Rasha Mohamed Abd El Rasoul

\section{- Insect colony :}

Bioassays were conducted using 4 th larval instar of the cotton leafworm, $S$. littoralis obtained as egg masses from an established laboratory colony in pest physiology laboratory, plant protection research institute, Sharkia branch (Egypt). Larvae were reared on castor bean leaves. The colony was maintained at $25 \pm 2^{\circ} \mathrm{C}, 60$ 70\%RH, and photoperiod 12:12 (L:D)h.

\section{- Bioassay of active fractions:}

After fractionation of $C$. sinensis and $C$. limon peels Hex extracts, the separated fractions were tested against the newly moulted $4^{\text {th }}$ larval instar to detect the active fraction that, later on, subjected to TLC and Gc/MS analyses. The petri dish residual exposure bioassay (Siskos et al.,2007) was used to evaluate the insecticidal activity of different citrus peel crude extracts against the larvae. In glass petri dishes (bottom, internal dimeter $9 \mathrm{~cm}$; hight, $1.5 \mathrm{~cm}$ ). serial concentrations of each fraction were prepared, and $1 \mathrm{ml}$ of each was spread on the bottom, and the petri dishes were rotated manually until solvent evaporation to achieve an even distribution of the sample. Three replicates of 10 randomly selected larvae were used for each extract. The larvae were introduced into petri dishes, and exposed to the extract for $30 \mathrm{~min}$. The insects were exposed to the extract through contact with the cuticle and probably also with prologs. Then, the larvae were transferred to clean dishes supplied with their food (castor bean leaves). Mortality was recorded after $72 \mathrm{hr}$ post-treatment. Control dishes were treated by the same manner with solvent only; the same number of larvae were introduced into these dishes, and controls were run simultaneously with the treatments.

The experiments were conducted in the laboratories of pest physiology department, plant protection Research Institute.

\section{- Statistics :}

Data obtained from bioassays were corrected for control mortality using Abbott's formula (1925). Fractionation and bioassay test were done in triplicates. Data obtained from Gc/Ms analyses were computed from Gc peak areas. 


\section{RESULTS AND DISCUSSION}

Peels from plants of the genus Citrus are obtained as waste by-products of the citrus processing industry. The citrus peels contain many secondary metabolites that are physiologically active to insects and could be used as natural botanical pesticides as ecofriendly products. So identification of such metabolites is of a valuable interest.

Amin et al. (2017) indicated that a potent contact larvicide can be obtained from Hex extracts of fresh lemon or orange peel. Fractionation of Hex crude extracts obtained 12 fractions for each citrus species, $\left(\mathrm{L}_{1}-\mathrm{L}_{12}\right)$ for lemon and $\left(\mathrm{O}_{1}-\mathrm{O}_{12}\right)$ for orange peel extracts. According to TLC analysis, similar fractions were added together, so lemon crude extract fractions was reduced to be 6 fractions, while that of orange crude extract was reduced to 4 fractions (Table, 1 ).

Bioassay test using contact method was performed on different fractions to detect the bioactive fractions toxic to $4^{\text {th }}$ larval instar of $S$. littoralis. The results (Table, 2) showed that lemon fractions were more toxic than those of orange.

Table 1. Fractions before and after TLC analysis.

\begin{tabular}{|l|l|l|}
\hline \multirow{2}{*}{ Fraction number } & \multicolumn{2}{|l|}{ Reduced fractions } \\
\cline { 2 - 3 } & C. limon & C. sinensis \\
\hline$F_{1}$ & $\mathrm{~L}_{1}$ & $\mathrm{O}_{1}$ \\
\hline $\mathrm{F}_{2}$ & $\mathrm{~L}_{2+3+4}$ & $\mathrm{O}_{2+3+4+5}$ \\
\hline $\mathrm{F}_{3}$ & $\mathrm{~L}_{5}$ & $\mathrm{O}_{6+7+8}$ \\
\hline $\mathrm{F}_{4}$ & $\mathrm{~L}_{6+7}$ & $\mathrm{O}_{9+10+11+12}$ \\
\hline $\mathrm{F}_{5}$ & $\mathrm{~L}_{8+9+10}$ & --- \\
\hline $\mathrm{F}_{6}$ & $\mathrm{~L}_{11+12}$ & --- \\
\hline
\end{tabular}

$F_{1-6}$ :Fractions after TLC analysis ; $L_{1-12}$ :Lemon fractions before TLC analysis ; $\mathrm{O}_{1-12}$ : orange fractions before TLC analysis.

Table 2. percentage mortality counts of $4^{\text {th }}$ larval instar of $S$. littoralis treated by contact method with different fractions of lemon and orange peel extracts.

\begin{tabular}{|l|l|l|}
\hline \multirow{2}{*}{} & \% corrected mortality \\
\cline { 2 - 3 } & C. limon & C. sinensis \\
\hline$F_{1}$ & 0.00 & 0.00 \\
\hline$F_{2}$ & 100 & $60(55-65)$ \\
\hline$F_{3}$ & 100 & $20.5(19-22)$ \\
\hline$F_{4}$ & 0.00 & 0.00 \\
\hline$F_{5}$ & 0.00 & ---- \\
\hline$F_{6}$ & 0.00 & ---- \\
\hline
\end{tabular}

- Data were corrected according to Abbott's formula (1925). 
$F_{2}$ and $F_{3}$ fractions of lemon peel extract showed $100 \%$ mortality after $72 \mathrm{hr}$ post treatment, while the highest mortality recorded for orange extract was $60 \%\left(F_{2}\right.$ fraction). $F_{3}$ caused low activity ( $20 \%$ mortality). The remaining factions i.e $F_{1}, F_{4}, F_{5}$ and $F_{6}$ of lemon extract, and $F_{1}$ and $F_{4}$ of orange extract did not show any toxicity against the larvae.

The most potent fractions of lemon and orange extracts were selected for further analysis to identify and compare the bioactive secondary metabolites present in such fractions. $F_{2}$ and $F_{3}$ fractions of both lemon and orange Hex peel extracts were subjected to GC/MS analysis, as they recorded the highest toxicity against the cotton leafworm.

The identification of individual components was based on comparison of mass spectral fragmentation patterns with those stored in the mass spectral library built up using pure substances and the mass spectra from the literature. The percentage of composition was computed from gas chromatography peak areas.

Many compounds were identified (Table 3 ) in the semi-purified $F_{2}$ and $F_{3}$ factions of orange extract. Although the two fractions differed in their bioactivity, they had approximately equal value of D-Limonene $(\approx 86 \%)$. However $F_{2}$ contained higher amounts of linalool, a-terpinol and citral than $\mathrm{F}_{3}$ fraction.

$F_{2}$ and $F_{3}$ fractions of Hex extracts of lemon peel caused $100 \%$ mortality, however there are variable metabolites eluted in the different fractions differ in their structure and physical properties, and might share in toxicity (table 4). $F_{2}$ fraction contained d-limonene(15.16\%), 3-carene (13.42\%), $\mathrm{y}$-terpinene(5.2\%), a-pinene (2.24\%) and a-fernesene (4.32\%). On the other hand, Fsfraction contained the overall highest amount of citral (42.03\%), followed by d-limonene (14.07\%), linalool $(5.11 \%), \beta$-pinene $(4.34 \%)$, $\beta$-myrcene $(3.37 \%)$, $\gamma$-terpinene $(1.62 \%)$ and terpinen4-ol (1.51\%). 
22 GAS CHROMATOGRAPHY COMBINED TO MASS SPECTROMETRY ANALYSES OF SOME CITRUS PEELS BIOACTIVE COMPOUNDS AGAINST THE COTTON LEAFWORM, SPODOPTERA LITTORALIS (BOISD.)

Table 3. The main constituents of fraction2 and fraction3 from navel orange Hex peel extract identified by GC-MS.

\begin{tabular}{|c|c|c|c|c|c|c|}
\hline \multirow[b]{2}{*}{ No. } & \multirow[t]{2}{*}{ Orange fraction 2} & \multicolumn{5}{|c|}{ Orange fraction 3} \\
\hline & & $\begin{array}{c}\mathrm{RT} \\
\text { (min.) }\end{array}$ & $\begin{array}{l}\text { Ratio } \\
(\%)\end{array}$ & Components & $\begin{array}{r}\mathrm{RT} \\
\text { (min.) } \\
\end{array}$ & $\begin{array}{l}\text { Ratio } \\
(\%)\end{array}$ \\
\hline 1 & a-pinene & 4.229 & 0.18 & a-pinene & 4.379 & 0.25 \\
\hline 2 & Bicyclo (3.1.0)-hexane & 4.957 & 0.22 & $\beta$-Myrcene & 5.163 & 1.70 \\
\hline 3 & $\beta$-Myrcene & 5.151 & 1.31 & a- Phelladerene & 5.391 & 0.06 \\
\hline 4 & Octanal & 5.329 & 0.54 & 3-Carene & 5.483 & 0.16 \\
\hline 5 & D-limonene & 5.707 & 85.57 & D-limonene & 5.786 & 86.94 \\
\hline 6 & 2-pyrrolidinone & 5.975 & 0.42 & $\mathrm{y}$-Terpinene & 6.204 & 0.07 \\
\hline 7 & Linalool & 6.645 & 1.76 & Linalool & 6.799 & 0.17 \\
\hline 8 & Cis- Verbenal & 6.777 & 0.08 & Limonene oxide & 7.411 & 0.04 \\
\hline 9 & limonene oxide & 7.446 & 0.22 & Geranial & 7.604 & 0.05 \\
\hline 10 & Citronllal & 7.623 & 0.09 & Naphthalene & 8.121 & 0.20 \\
\hline 11 & Terpineol & 7.995 & 0.89 & a- Terpineol & 8.201 & 0.08 \\
\hline 12 & Hexadecane & 8.379 & 0.38 & Decanal & 8.361 & 0.10 \\
\hline 13 & Geranial & 8.487 & 0.57 & Citral & 9.817 & 0.10 \\
\hline 14 & 2,6,10-dodecatrien-1-ol & 8.739 & 0.38 & Caryophyllene & 11.44 & 0.08 \\
\hline 15 & Carvone & 8.997 & 0.06 & a -Famesene & 11.56 & 0.04 \\
\hline 16 & Citral & 9.100 & 0.26 & n-Hexadecanoic acid & 17.945 & 0.26 \\
\hline 17 & $\begin{array}{l}\text { 1,6-hexanediol } \\
\text { dimethacrylate }\end{array}$ & 9.151 & 0.21 & Linoelaidic acid & 20.263 & 0.29 \\
\hline 18 & 2,6-octadienal & 9.323 & 0.23 & $\begin{array}{l}\text { Heptamethoxy } \\
\text { flavon }\end{array}$ & 25.865 & 4.17 \\
\hline 19 & 2(3H)-Naphthalenone & 16.252 & 0.22 & $\begin{array}{l}\text { Hexamethoxy } \\
\text { flavone }\end{array}$ & 26.105 & 2.36 \\
\hline 20 & n-Hexadecanoic acid & 17.969 & 2.11 & $\begin{array}{l}\text { 9H-Fluorene- } \\
\text { 2-carboxylic acid }\end{array}$ & 26.408 & 0.21 \\
\hline 21 & Linoelaidic acid & 20.229 & 0.24 & $\begin{array}{l}\text { Methyltris(trimethyl } \\
\text { siloxy)silane }\end{array}$ & 26.551 & 0.25 \\
\hline 22 & $\begin{array}{c}9,12,15 \text {-octadecatrien- } \\
1 \text {-ol } \\
\end{array}$ & 20.303 & 1.35 & - & - & - \\
\hline 23 & $\begin{array}{c}4,5,6,7,8 \text { pentamethoxy } \\
\text { flavone }\end{array}$ & 29.407 & 0.89 & - & - & - \\
\hline & Total & & 98.18 & & & 97.58 \\
\hline
\end{tabular}

RT :retention time. 
Table 4. The main constituents of fraction2 and fraction3 from lemon Hex peel extract identified by GC-MS.

\begin{tabular}{|c|c|c|c|c|c|c|}
\hline \multirow[b]{2}{*}{ No. } & \multicolumn{3}{|l|}{ Lemon fraction2 } & \multicolumn{3}{|l|}{ Lemon fraction3 } \\
\hline & Components & $\begin{array}{c}\mathrm{RT} \\
(\min .) \\
\end{array}$ & $\begin{array}{l}\text { Ratio } \\
(\%)\end{array}$ & Components & $\begin{array}{l}\text { RT } \\
(\min .) \\
\end{array}$ & $\begin{array}{l}\text { Ratio } \\
(\%)\end{array}$ \\
\hline 1 & Bicyclo(3.1.0)hexene & 4.281 & 0.22 & Bicyclo(3.1.0)hexane & 4.940 & 0.49 \\
\hline 2 & a -Pinene & 4.390 & 2.24 & $\beta$-pinene & 4.997 & 4.34 \\
\hline 3 & 3-Carene & 5.037 & 13.42 & $\beta$-myrcene & 5.169 & 3.37 \\
\hline 4 & D-Limonene & 5.809 & 15.16 & D-Limonene & 5.769 & 14.07 \\
\hline 5 & $\beta$-Ocimene & 6.072 & 0.72 & Tricyclo(2.2.1.0[2,6])heptane & 5.849 & 1.28 \\
\hline 6 & Y-Terpinene & 6.295 & 5.20 & $\beta$-Ocimene & 6.021 & 2.08 \\
\hline 7 & Decane & 6.370 & 0.28 & $\gamma$-Terpinene & 6.204 & 1.62 \\
\hline 8 & 4-Carene & 6.684 & 2.35 & 2-Carene & 6.673 & 0.41 \\
\hline 9 & Citronllal & 7.603 & 0.10 & Linalool & 6.834 & 5.11 \\
\hline 10 & Decanal & 8.367 & 0.29 & 2,4,6-octatriene & 7.246 & 0.86 \\
\hline 11 & Citral & 8.916 & 1.55 & Terpinen-4-ol & 8.024 & 1.51 \\
\hline 12 & Geranyl acetate & 10.839 & 0.31 & Decanal & 8.367 & 0.70 \\
\hline 13 & Cyclohexane & 11.056 & 2.11 & oxiranecarboxaldehyde & 8.653 & 0.62 \\
\hline 14 & Caryophyllene & 11.485 & 3.75 & Citral & 8.985 & 42.03 \\
\hline 15 & Trans-a-Bergamatene & 11.623 & 4.80 & 4-methyl-1,5-Heptadiene & 10.582 & 1.08 \\
\hline 16 & trans- a -Bergamotene & 11.348 & 0.25 & Bicyclo(2.1.0)pentane & 10.759 & 0.24 \\
\hline 17 & (E)- $\beta$-Famesene & 11.806 & 0.48 & Geranyl acetate & 10.833 & 0.37 \\
\hline 18 & Humulene & 11.909 & 0.78 & Dodecanal & 11.171 & 0.38 \\
\hline 19 & $\begin{array}{l}\text { 8-Isopropyl-1-methyl-5- } \\
\text { methylenecyclodeca-1,6-diene }\end{array}$ & 12.241 & 1.01 & 3,5-heptadienal & 11.360 & 0.24 \\
\hline 20 & Naphthalene & 12.315 & 0.21 & Caryophyllene & 11.446 & 0.53 \\
\hline 21 & cis- a -Bisabolene & 12.424 & 0.68 & trans- $a$-Bergamotene & 11.583 & 0.66 \\
\hline 22 & a -Farnesene & 12.515 & 4.32 & a -Farnesene & 12.447 & 0.54 \\
\hline 23 & $\beta$-Bisabolene & 12.561 & 6.89 & $\beta$-Bisabolene & 12.498 & 1.24 \\
\hline 24 & Benzene 1- butyllhexyl & 12.841 & 3.61 & Benzene -1- pentylhexyl & 13.935 & 0.93 \\
\hline 25 & $\gamma$-Elemene & 13.208 & 3.33 & 1,3,6,10-Dodecatetraene & 14.003 & 0.42 \\
\hline 26 & Benzene-1- butylheptyl & 14.020 & 4.37 & Benzene -1- ethylnonyl & 14.329 & 1.15 \\
\hline 27 & Benzene -1- pentylheptyl & 15.119 & 2.82 & $\begin{array}{l}\text { 4-(2,2-Dimethyl-6- } \\
\text { methylenecyclohexyl)butanal }\end{array}$ & 14.478 & 0.77 \\
\hline 28 & Benzene -1- propylnonyl & 15.342 & 2.01 & alpha-Bisabolol & 14.627 & 2.01 \\
\hline 29 & Hexadecanal & 16.200 & 12.65 & n-Hexadecanoic acid & 18.020 & 2.59 \\
\hline 30 & Octadecane & 28.457 & 8.60 & Linoelaidic acid & 20.229 & 0.69 \\
\hline 31 & & - & - & cis-Vaccenic acid & 20.292 & 0.69 \\
\hline 32 & & - & - & $\begin{array}{l}\text { 7H-Furo(3,2-g) (1) benzopyran- } \\
\text { 1-one }\end{array}$ & 21.505 & 2.61 \\
\hline 33 & & - & - & 1.3-Butanedione & 28.400 & 0.83 \\
\hline Total & & & 96.5 & & & 96.4 \\
\hline
\end{tabular}

The GC-MS pattern of the toxic fractions of lemon and orange peel extracts illustrated in fig. $(1,2,3,4)$. 
24 GAS CHROMATOGRAPHY COMBINED TO MASS SPECTROMETRY ANALYSES OF SOME CITRUS PEELS BIOACTIVE COMPOUNDS AGAINST THE COTTON LEAFWORM, SPODOPTERA LITTORALIS (BOISD.)

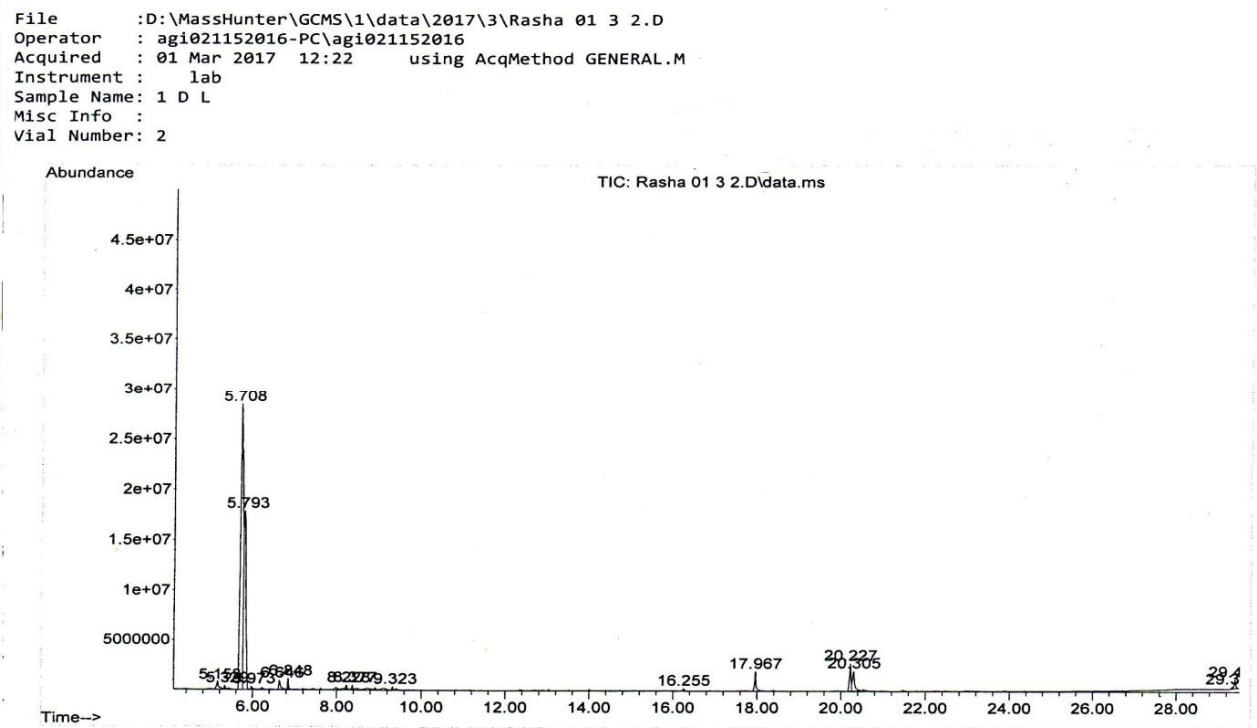

Fig. 1. Chromatogram (GC-MS) of fraction2 from navel orange Hex peel extract.

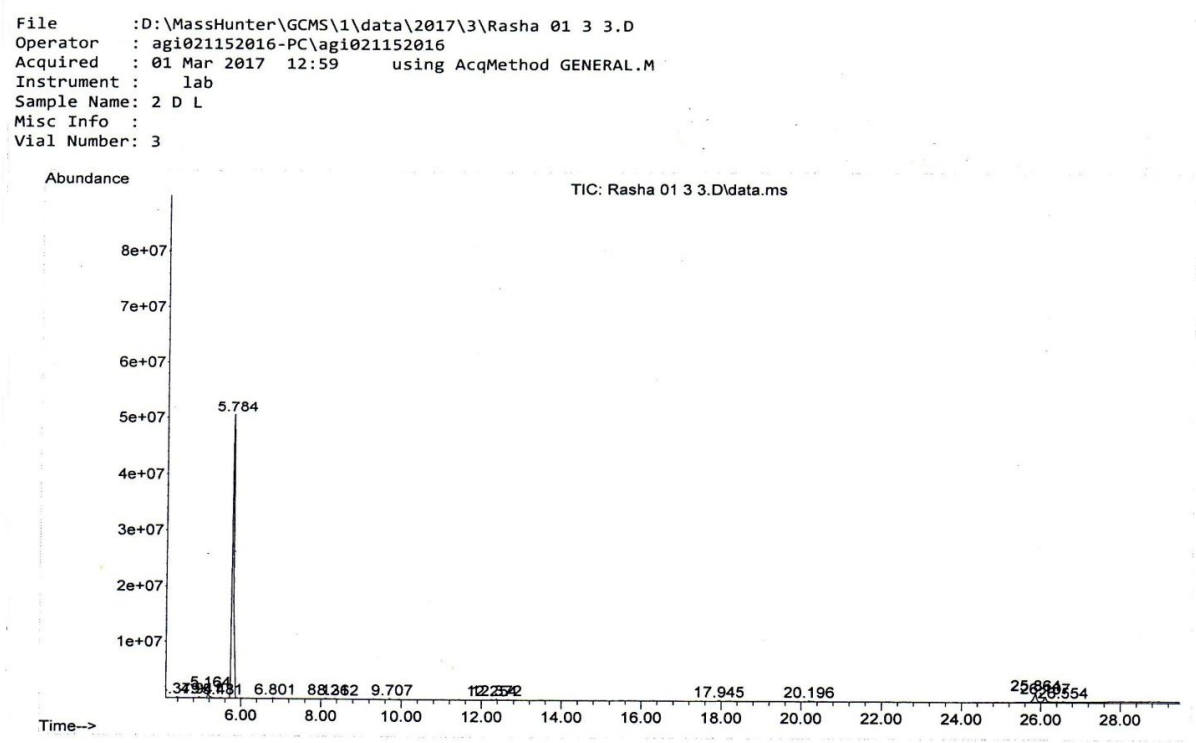

Fig. 2. Chromatogram (GC-MS) of fraction 3 from navel orange Hex peel extract. 


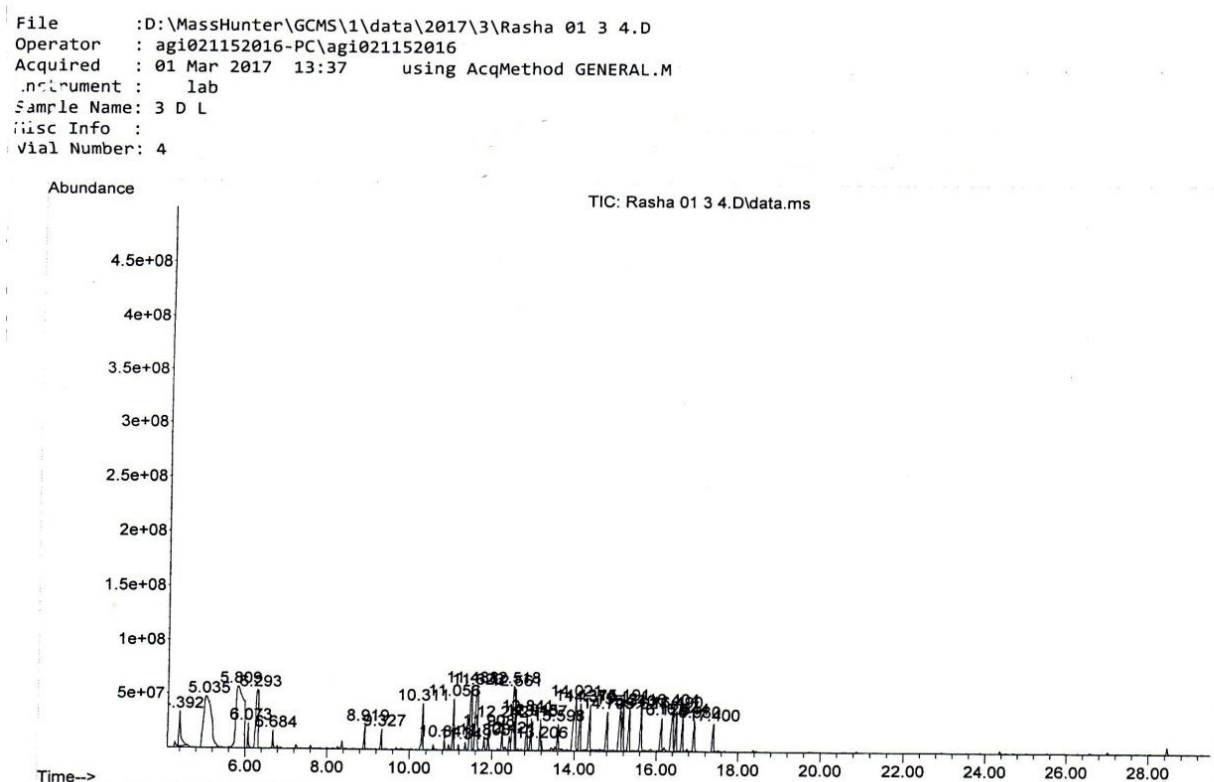

Fig. 3. Chromatogram (GC-MS) of fraction 2 from lemon Hex peel extract.

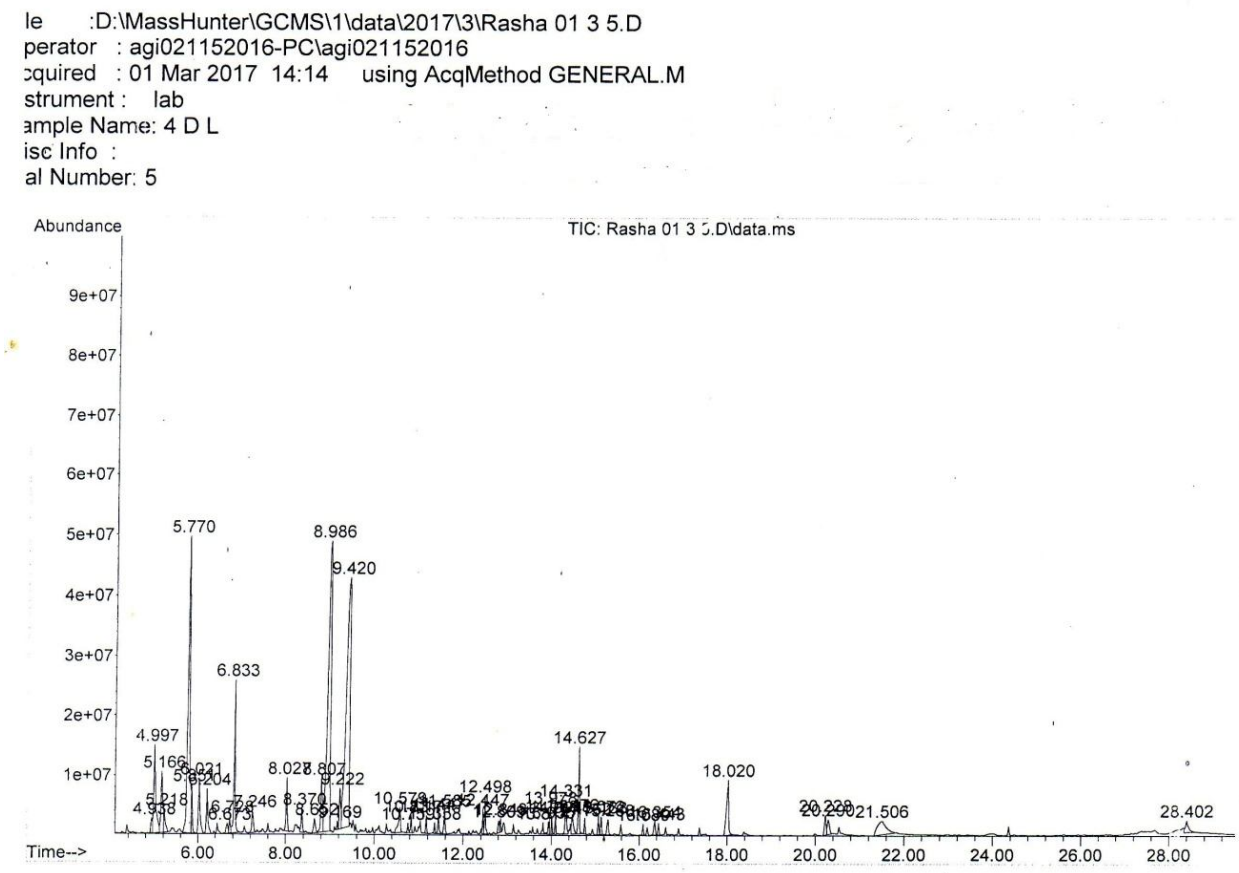

Fig. 4. Chromatogram (GC-MS) of fraction 3 from lemon Hex peel extract.

The active fractions of lemon and orange peel extracts contained D-limonene, a-pinene, linalool, citronllal and citral. Limonene oxide, Geranial and terpineol were only detected in orange peel extract. The results indicated that secondary metabolites 
quality and quantity differ according to the Citrus spp., and quantity of D-limonene is much lower in lemon extract, while it is a major compound in both extracts.

The variation of the composition of secondary metabolites of citrus peel as shown between lemon and orange peel extracts, might be depend on the Citrus spp. . However, there are some factors that affect the citrus composition such as collection time, temperature, humidity, sun exposure and extraction method (Dutra et al., 2016). Here a through comparative study between lemon and orange, the extraction procedure, type of solvent and GC-MS conditions were identical for all samples and therefore, the influence of technical parameters on the chemical composition of peel extracts was negligible.

There are much reviews about comparison between orange and lemon constituents (Campolo et al., 2014 ; Mickaelkis et al. , 2009 ; Parastar et al. , 2012). They agree that orange contains higher content of d-limonene than lemon. It seems that there are other active compounds in citrus extract besides $d$-limonene that add to toxicity of lemon or orange peel extracts. Although d-limonene has insecticidal capacity, it showed lower toxicity than oils when used alone, since insecticidal activity may also affected by minor compounds (Martins et al., 2017).

In addition to the monoterpenoids; d-limonene [(R)-4-isopropenyl-1methylcyclo-hexane], there are many active compounds have insecticidal activity like citral (mixture of neral and gernial) (Salvatore et al., 2004), a-terpineol , $\beta$-myrcene , linalool and pulegone (Coats et al. , 1991).Some authors found that there are secondary metabolites in citrus, and more active than limonene. Citral was the most efficient monoterpenoid, followed by limonene, then a-pinene and a-terpineol, against larvae of the Caribbean fruit fly (Styer and Greany, 1983). $\beta$-pinene revealed stronger toxicity than many already known p-menthane type molecules such as $\mathrm{S}-(+)-$ limonene, carvone, menthane and menthol (Mickealkis et al., 2008). A cyclic type compounds such as nerol, gerniol and neryl acetate were also recorded in citrus essential oils (Mickealkis et al., 2009).

It is difficult in the present work, to implicate certain compound(s) in toxicity of the studied extracts. We found th at d-limonene content was $\approx 15 \%$ in lemon extract fractions, which showed very high toxicity as compared to orange extract fractions ( $\approx 85 \% \mathrm{~d}$-limonene). Also, both fractions $\left(\mathrm{F}_{2}\right.$ andF $\left.\mathrm{F}_{3}\right)$ had different mixtures of metabolites with different quantities. If it is supposed that citral in $F_{3}(42.03 \%)$ might responsible for toxicity, the situation become not valid, because $F_{2}$ which showed the same toxicity had relatively low value of citral $(1.55 \%)$. The toxic factors seem not only depend on citrus spp., but also on fraction level in citrus extracts.

Lemon essential oil is a mixture of many p-menthane-type molecules, which are known for their larvicidal toxicity, and subsequently, it may be concluded why $\mathrm{LC}_{50}$ value revealed stronger toxicity compared to other Citrus species (Mickealkis et al., 2009). This might explains why lemon extracts fractions were more toxic than orange 
extracts fraction, regardless of the d-limonene content observed in the present work. Martins et al. (2017) found that sweet orange ( $C$. sinensis) and Silcian lemon ( $C$. limon) contained 83.33 and $59.78 \%$ d-limonene, respectively. The sweet orange oil presented lethal concentration against Dymicoccusbrevips at $2.21 \%$ (LC50) and the Silcilian lemon oil at $0.72 \%\left(\mathrm{LC}_{50}\right)$, indicating that lemon was more toxic than orange oil.

The results suggest that citrus extract contains many compounds, other than limonene, are toxic and/or potentiate each other to give the observed toxicity. Jiang et al. (2009) mentioned that insecticidal activity may also affected by minor compounds which promote a synergism with the major constituents, thus increasing mortality.

It could be concluded that the quantity of d-limonene is not the determinant factor, but it is probable that other metabolites confer toxicity allover citrus extract depending on the species.

\section{REFERENCES}

1. Abbott, W.S. 1925. A method of computing the effectiveness of an insecticide. J. Econ. Entomol., 18;265-267.

2. Adams, R.P. 2007. Identification of essential oil components by gas chromatography mass spectroscopy. $4^{\text {th }}$ ed., Carol Stream : Allured publishing Corp.,p. 804.

3. Amin,Lobna R.; S. Abo El-Enin; A. M. Abdel-Ghany; S.S.El-Badawy and T.R.Amin. 2017. Physicochemical and phytochemical analysis of some Citrus peel extracts, and their activity against the cotton leafworm, Spodopteralittoralis (Boisd.) (Lepidoptera :Noctuidae). Egypt. J.Agric.Res : (In press).

4. Campolo, O.; A. Malacrino; L. Zappala; FF. Laundani; E.Chiera ; D.Serra ; M. Russo and V. Palmeri. 2014. Fumigant bioactivity of five Citrus essential oils against Triboliumconfusum.Phytoparastica, 42:223-233.

5. Coats, J.R.; L.L.Karr and C.D.Drewes. 1991. Toxicity and neurotoxic effects of monoterpenoids : in insects and earthworm. Entomology publications. Iowa state Univ., 304-316.

6. Da Silva Branco, E.; J.D. Vendramin and F. Denardi. 2000. ResistênciaásMoscasdas-frutasemfruteiras, pp. 161-167, in A.Malavasiand and R.A. Zucchi (eds.). Moscas-das-frutas de ImportánciaEconômica no Brazil. HolosEditora, RiberâoPerto, Brazil.

7. Dutra, K.A.; J.V. Oliveira; D.M.A.F.Navarro; D.R.S.Barbosa and J.P.O.Santos. 2016. Control of Callosobruchus maculates (FABR.)(Coleaptera:Chrysomelidae:Bruchinae) in Vignaunguiculata (L.) WALP. with essential oils from four Citrus spp. plants. J.stored products Res.,68:25-32. 
28 GAS CHROMATOGRAPHY COMBINED TO MASS SPECTROMETRY ANALYSES OF SOME CITRUS PEELS BIOACTIVE COMPOUNDS AGAINST THE COTTON LEAFWORM, SPODOPTERA LITTORALIS (BOISD.)

8. Jiang,Z.; Y.Akhtar ; R.Bradbury and MB Isman. 2009. Comparative toxicity of essential oils of Litseapungens and Litseacubeba and blends of their major constituents against the cabbage looper, Trichoplusiani. J. Agric. Food Chem., Washington, 57:4833-4837.

9. Kirchner, J.G. 1978. " Thin layer chromatography", techniques of chemistry series, V. XIV , $2^{\text {end }}$ Edition,E. S. Perry (ed.), A Wilet-Interscience Pub.,New York.

10. Loh, F.S.; R.M.Awang; D.Omar and M. Rahmani. 2011. Insecticidal properties of Citrus hystrix DC leaves essential oil against spodopteraliturafabricius. J.Med. plant Res., 5:3739-3744.

11. Martins G.O.O; H.B.Zago; A.V.Costa; L.M.D.Junior and J.R. De Carvalho. 2017. Chemical composition and toxicity of citrus essential oils on Dysmicoccusbrevipes (Hemiptera: Pseudococcidae). Rev. Caatinga, Mossoro, 30:811-817.

12. Michaelakis, A.; D. Papachristes; A. Kimbaris; G. Koliopoulos; A. Giatropoules and M.G. Polissiou. 2009. Citrus essential oils and four enantiomericpinenes against Culexpipiens (Diptera: Culicidae). Parasitol Res., 105:769-773.

13. Mickaelkis, A.; G.Koliopouls; P. Milonas; D.Kontodimas; M. Polissiou; A-C Kimbaris and D. Papachristes. 2008. Activity of monoxygenated versus oxygenated monoterpenes against mosquitoes. An attempt to correlate toxicity with chemical structure. In :A $7^{\text {th }}$ joint meeting of AFERP, GA, PSEaSIF, Athens.

14. Murugan, K.; P.M.Kumar; K.Kovendan; D.Amersan; J.Subrmoniam and J.Hwang 2012. Larvicidal, pupicidal, repellent and adulticidal activity of Citrus sinensis orange peel extract against Anopheles stephensi, Aedesaegypti and Culexquinquefasciatus (Diptera: Culicidae). Parasitol Res., 111:1757-1769.

15. Parastar,H.; M. Jalali-Heravi; H.Sereshti and A. Mani-Varnosfaderani. 2012. Chromatographic fingerprint analysis of secondary metabolites in citrus fruits peels using gas chromatography-mass spectrometry combined with advanced chemometric methods. J. chromatography A, 1251:176-187.

16. Salvatore, A.; S.Borkosky; E.Willink and A.Bardon. 2004. Toxic effects of lemon peel constituents on Ceratitiscapitata. Journal of chemical ecology, 30:323-333.

17. Sattar, A. and S. Mahmud. 1992. Citrus oil, composition of monoterpenes of the peel oil of orange, Kinnow, and lemon. Pak.J.Sci Ind. Res., 29:196-198.

18. Siskos, E.P.; M.A. Konstantopoulou; B.E. Mazomenos and M. Jervis (2007). Insecticidal activity of Citrus aurantium fruit, leaf and shoot extracts against adult olive fruit flies (Diptera: Terphritidae). J. Econ. Entomol., 100:1215-1220.

19. Styer, S.C. and P.D.Greany. 1983. Toxicity of toxic oils. Environ. Entomol., 12:1606-8.

20. Weiss, E.A. 1997. Essential oil crops. CAB international, Walling ford.

21. Yamaski, Y.; H. Kunoh ; H. Yamamoto and K. Akimitsu. 2007. Biological roles of monoterpene volatiles derived from rough lemon (Citrus Jambhiri Lush) in citrus defense. J.Gen. Pathol., 73:168-179. 


\title{
"التحليل الكروماتوجر افي للمكونات الطبيعية لقشور بعض الموالح الفعالة" ضد دودة ورق القطن"
}

\author{
لبنى رئيس أمين'، صلاح عبد الغني أبو العينين'، أحمد مليجي عبدالغني'، \\ سامي سبد البدوي' ، طارق رئيس أمين' . \\ 1 - معه بحوث وقاية النباتات، مركز البحوث الزراعية ، الدقي- جيزة. \\ r- قسم الكيمياء ، كلية العلوم ، جامعة عبن شعس.
}

تم في هذه الدراسة استخدام مذيب الهكسان لاستخلاص مكونات قشور البرتقال و الليمون

الطازجة وذللك لفصل و تعريف المكونات الفعالة ضد العمر اليرقي الر ابع لدودة ورق القطن -

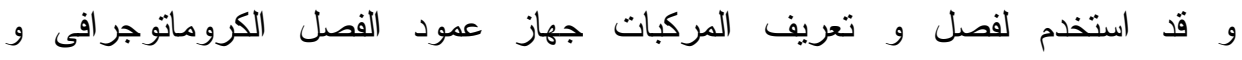
كروماتوجر اف الطبقةالرقيقة (TLC) و جهاز الكروماتوجر اف الغازي -الكتلي · و قد اثبت استخدام هذه التقنيات كفاءة العمل على قثنور الموالح

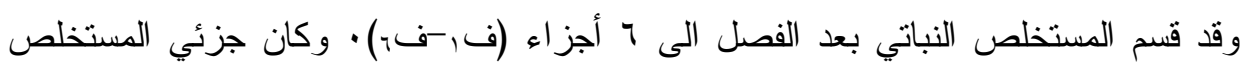
فr ،فت من قشور الليمون و البرتقال هما الفاعلين ضد الآفة. وقد اثشترك كلا من قشتور الليمون و البرتقال في احتو ائها على .d- limonene, a-pinene, linalool, citral, citronllal.و لكن فنشور

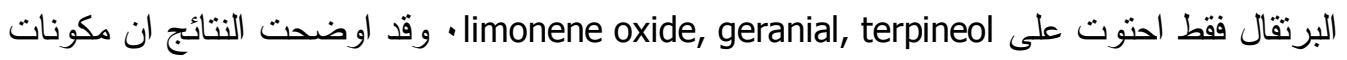

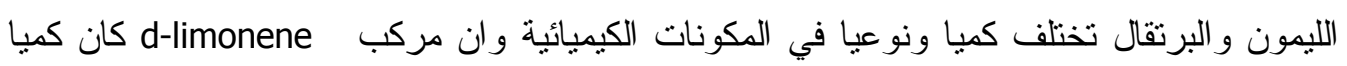

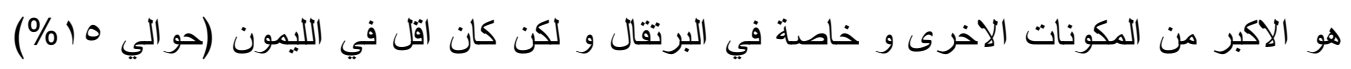

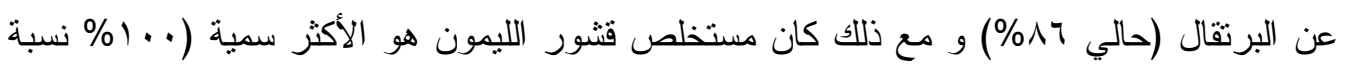

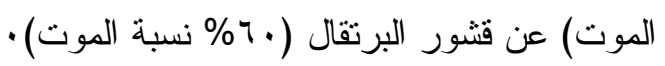

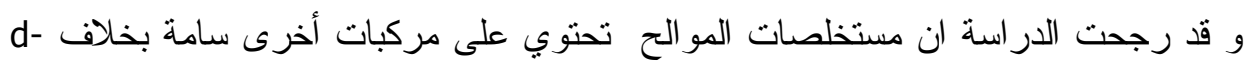
limonene الملاحظة في التجارب • و الخلاصة ان مركب d-limonene ليس هو العامل المحدد للسمية في الليمون و البرتقال و ان العوامل المحدة للفاعلية قد تختلف حسب صنف المو الح. 